\title{
Pernikahan Siri dalam Tinjauan Hukum Islam dan Undang-Undang Nomor 1 Tahun 1974 Tentang Perkawinan
}

\author{
Universitas Tidar Magelang \\ faridaidd01@gmail.com
}

Farid Pardamean Putra Irawan ${ }^{凶}$, Nur Rofiq

\begin{abstract}
Marriage is an agreement between a man and a woman to form a family and live together until the end of life. In Islam, unregistered marriage is known as a marriage that is legally valid in religion but not under state law. Siri marriage is very thick and inherent in practice in Islamic societies which tend to still think that religiously validity is sufficient, without the need for registration by the state as a legal marriage as stipulated in Law Number 1 of 1974 concerning Marriage. The purpose of this research was carried out to try to examine in more depth the connection between siri marriage in the view of Islamic law and state law. The method used in this research is normative legal research or library research by examining document studies, namely using various secondary data such as statutory regulations, court decisions, legal theory, and it can be in the form of the opinions of scholars. This type of normative research uses qualitative analysis by explaining existing data in words or statements not with numbers. From the results of the research carried out, it was explained that carrying out a siri marriage is allowed by the state but with the consequence the power of law in solving problems due to the siri marriage.
\end{abstract}

\section{Keywords: Siri Marriage; State Law; Islamic Law}

\begin{abstract}
Abstrak
Pernikahan adalah perikatan antara seorang lelaki dan seorang perempuan untuk membentuk suatu keluarga dan hidup bersama sampai akhir hayat. Dalam islam dikenal pernikahan siri yaitu pernikahan yang sah secara agama tetapi tidak secara aturan hukum negara. Pernikahan siri sangat kental dan melekat praktiknya dalam masyarakat islam yang cenderung masih beranggapan bahwa sah secara agama sudah cukup, tanpa perlu untuk dilakukan pencatatan oleh negara sebagai pernikahan yang sah seperti diatur dalam Undang-Undang Nomor 1 Tahun 1974 Tentang Perkawinan. Tujuan Penelitian ini dilaksanakan untuk mencoba mengkaji secara lebih mendalam terkait pernikahan siri dalam pandangan hukum islam dan hukum negara. Metode yang digunakan dalam penelitian ini adalah penelitian hukum normatif atau penelitian perpustakaan dengan mengkaji studi dokumen, yakni menggunakan berbagai data sekunder seperti peraturan perundang-undangan, keputusan pengadilan, teori hukum, dan dapat berupa pendapat para sarjana. Penelitian jenis normatif ini menggunakan analisis kualitatif yakni dengan menjelaskan data-data yang ada dengan kata-kata atau pernyataan bukan dengan angkaangka. Dari hasil penelitian yang dilaksanakan menjelaskan bahwa melakukan pernikahan siri diperbolehkan oleh negara tetapi dengan konsekuensinya kekuatan hukum dalam menyelesaikan masalah akibat pernikahan siri tersebut.
\end{abstract}

Kata Kunci : Pernikahan Siri; Hukum Negara; Hukum Islam

Received: 2021-06-12 Accepted: 2021-06-30 Published: 2021-06-30 


\section{Pendahuluan}

Pernikahan adalah salah satu tujuan manusia dalam hidup. Setiap manusia pasti mempunyai keinginan untuk menikah. Pernikahan sendiri dimaknai sebagai suatu ikatan laki-laki dan perempuan untuk membentuk keluarga. Pernikahan di Indonesia diatur berdasarkan Undang-Undang Nomor 1 Tahun 1974 Tentang Perkawinan. ${ }^{1}$ Pernikahan dilakukan di kantor urusan agama bagi mereka yang beragama islam sedangkan untuk mereka yang beragama selain islam di kantor catatan sipil.

Dalam agama islam terdapat 2 (dua) pandangan terkait pemahaman akan pernikahan ini yaitu pernikahan yang sah secara agama serta negara dan pernikahan yang sah secara agama saja atau disebut juga nikah siri. Pernikahan yang sah secara agama dan negara adalah pernikahan yang dicatat di kantor urusan agama dan juga sesuai dengan pedoman agama islam. Sedangkan nikah siri adalah pernikahan yang berdasarkan pedoman agama islam saja, tetapi tidak diakui dan dicatat oleh negara. ${ }^{2}$ Sesuai dengan Undang-Undang Nomor 23 Tahun 2006 Tentang Administrasi Kependudukan Pasal 15, Pasal 16, dan Pasal 17 bahwasannya pencatatan sipil adalah pencatatan suatu peristiwa penting dialami seseorang dan peristiwa tersebut yang disebutkan dalam aturan pencatatan sipil seperti: kelahiran, kematian, lahir mati, perkawinan, perceraian, pengakuan anak, pengesahan anak, pengangkatan anak, perubahan nama dan perubahan status kewarganegaraan. ${ }^{\mathbf{3}}$

Sehingga sudah seharusnya pernikahan tersebut dicatatkan oleh negara melalui instansi terkait agar kedudukan serta kekuatan hukum pernikahan bersifat tetap dan jelas. Apabila hal tersebut tidak dilakukan oleh kedua calon suami istri maka dikhawatirkan kedepannya akan timbul masalah-masalah terkait status keduanya nanti. Sudah sejak lama praktik pernikahan siri ini mengakar kuat di Indonesia khususnya bagi para calon pasangan yang harus melangsungkan pernikahan muda. Karena cara tersebut dianggap tepat guna menutup aib keluarga serta menghemat biaya

1 "UU No. 1 Tahun 1974 Tentang Perkawinan," Pub. L. No. 1 (n.d.), https://peraturan.bpk.go.id/Home/Details/47406/uu-no-1-tahun-1974.

2 Vivi Kurniawati, Nikah Siri, ed. oleh Fatih, 1 ed. (Jakarta: Rumah Fiqih Publishing, 2019), https://www.rumahfiqih.com/pdf/x.php?id=171\&nikah-siri.htm.

3 "UU No. 23 Tahun 2006 Tentang Administrasi Kependudukan," Pub. L. No. 23 (n.d.), https://peraturan.bpk.go.id/Home/Details/40202. 
pernikahan disebabkan faktor ekonomi yang belum siap. Untuk itu penelitian tentang pernikahan siri ini telah banyak sekali dilakukan karena menarik dan penting sekali dikaji secara lebih mendalam. Atas dasar tersebut peneliti tertarik untuk melakukan penelitian tentang pernikahan siri dalam ruang lingkup peraturan umumnya serta peraturan di dalam islam.

\section{Metode Penelitian}

Penelitian ini termasuk jenis penelitian hukum normatif dengan mengkaji menggunakan berbagai data sekunder seperti peraturan perundang-undangan, keputusan pengadilan, teori hukum, dan pendapat para sarjana. Penelitian jenis normatif ini menggunakan analisis kualitatif yakni dengan menjelaskan data-data yang dikaji dan disajikan dalam bentuk narasi. Cara penelitian ini dilakukan dengan mengkaji bahan-bahan sekunder berupa undang-undang dan peraturan-peraturan hukum negara maupun dalam hukum islam. Metode analisis data ini dilakukan secara deskriptif-kualitatif berdasarkan hasil kajian bahan-bahan kepustakaaan dan landasan teori-teori disertai dengan argumen-argumen yang berkaitan dengan praktik pernikahan siri yang terjadi.

\section{Hasil dan Pembahasan}

\section{Pernikahan siri dalam pandangan hukum islam dan hukum negara}

Nikah siri sangat dilarang dan bertentangan dengan hukum negara berdasarkan UU No. 1 Tahun 1974 tidak sama sekali mengatur maupun memperkuat posisi kedudukan dari pernikahan siri. Ketentuan pernikahan siri juga sangat tidak dianjurkan oleh Kementerian Agama yang menegaskan suatu pernikahan harus berdasarkan agama islam juga perlu dicatat di kantor urusan agama (KUA). Sementara pengertian perkawinan itu sendiri berdasarkan Undang-Undang No. 1 Tahun 1974 Tentang Perkawinan Pasal 1: Perkawinan adalah ikatan lahir batin antara seorang pria dan seorang wanita sebagai suami istri dengan tujuan membentuk keluarga (rumah tangga) yang bahagia dan kekal berdasarkan Ketuhanan Yang Maha Esa. ${ }^{\mathbf{4}}$ Lain halnya pengertian perkawinan menurut hukum adat, Perkawinan dalam arti "perikatan adat" ialah

\footnotetext{
${ }^{4}$ UU RI No. 16 Tahun 2019 Tentang Perubahan Atas Undang-Undang No. 1 Tahun 1974 Tentang Perkawinan \& Kompilasi Hukum Islam, 1 ed. (Bandung, Indonesia: Citra Umbara, n.d.).
} 
perkawinan yang mempunyai akibat hukum terhadap hukum adat yang berlaku dalam masyarakat bersangkutan. Perkawinan menurut Hukum Adat tidak hanya berarti suatu ikatan antara pria dengan wanita sebagai suami istri, tetapi juga dipandang sebagai sesuatu yang sakral dikarenakan mereka percaya para leluhur ikut serta dalam Page | 38 memberikan restu kepada calon pasangan oleh karena itu prosesnya sangat diperhatikan dan tidak sembarangan. Perkawinan dalam aturan hukum islam yaitu merupakan suatu perintah dari Allah yang sangat kuat atau miitsaaqon gholiidhan untuk menjalankan perintahnya. ${ }^{\mathbf{5}}$

Selanjutnya pada Kompilasi Hukum Islam (KHI) Pasal 3 menyebutkan bahwa tujuan dari diadakannya perkawinan tersebut untuk mewujudkan kehidupan keluarga yang sakinah, mawaddah, dan rahmah. Dengan tujuan tersebut mensyaratkan suatu pernikahan tersebut harus memberikan kepastian, jaminan dan perlindungan dalam membentuk suatu keluarga yang harmonis. Syarat Perkawinan diatur menurut UndangUndang Nomor 1 Tahun 1974 Tentang Perkawinan. Pertama, perkawinan dilakukan atas persetujuan dari calon pasangan. Kedua, perkawinan tersebut dilaksanakan berdasarkan kepercayaan dan adat istiadatnya masing-masing selama tidak bertentangan dengan undang-undang. Ketiga, perkawinan tersebut juga harus disetujui oleh kedua orang tua calon pasangan. Keempat, jika salah satu dari kedua orang tua calon pasangan meninggal cukuplah meminta persetujuan dari orang tua yang masih hidup. Kelima, apabila kedua orang tua sudah meninggal persetujuan dapat dimintakan melalui wali yang mengurusinya. Selanjutnya terkait tata cara perkawinan itu sendiri terdapat dalam Peraturan Pemerintah RI No. 9 Tahun 1975 Tentang Pelaksanaan Undang-Undang No. 1 Tahun 1974 Tentang Perkawinan pada Bab III Pasal 10 huruf b yang berbunyi: Tatacara perkawinan dilaksanakan menurut hukum masing-masing agamanya dan kepercayaannya itu dan huruf c yang berbunyi: Dengan mengindahkan tatacara perkawinan menurut masing-masing hukum agamanya dan kepercayaannya itu,

5 Mahkamah Agung RI, HIMPUNAN PERATURAN PERUNDANG-UNDANGAN YANG BERKAITAN DENGAN KOMPILASI HUKUM ISLAM SERTA PENGERTIAN DALAM PEMBAHASANNYA, ed. oleh Mahkamah Agung RI, 1 ed. (Jakarta: PERPUSTAKAAN DAN LAYANAN INFORMASI BIRO HUKUM DAN HUMAS BADAN URUSAN ADMINISTRASI MAHKAMAH AGUNG REPUBLIK INDONESIA, 2011), https://perpustakaan.mahkamahagung.go.id/assets/resource/ebook/23.pdf. 
perkawinan dilaksanakan dihadapan Pegawai Pencatat dan dihadiri oleh dua orang saksi. ${ }^{6}$

\section{Page | 39 Kedudukan Anak dan Harta Dalam Pernikahan siri}

Perkawinan siri dalam praktiknya dianggap tetap sah dilakukan dengan memenuhi syarat dan rukun islam, tetapi dalam hal ini akan mengakibatkan kerugian bagi pihak istri dan anak karena kedudukan mereka dalam pernikahan siri tidak diakui negara secara hukum. Dalam Undang-Undang Nomor 1 Tahun 1974 Tentang Perkawinan dan Kompilasi hukum islam secara tegas menjelaskan kedudukan istri dalam perkawinan siri tidak mempunyai kekuatan dalam hukum. Selain itu bagi suami istri yang melakukan pernikahan siri juga tidak akan mendapatkan hak-hak yang diberikan pemerintah kepada pasangan yang sah secara hukum negara dan agamanya. ${ }^{\mathbf{7}}$

Disebutkan di dalam Kompilasi Hukum Islam Pasal 6 bahwa setiap pernikahan yang dilaksanakan atas sepengetahuan pegawai pencatatan pernikahan yang berhak mencatat peristiwa pernikahan tersebut. Maka suatu pernikahan yang tidak dicatat oleh pegawai pencatatan pernikahan tidak sah. Bahkan dalam Peraturan Pemerintah Nomor 9 Tahun 1975 Pasal 45 menyebutkan pernikahan siri sebagai suatu pelanggaran. ${ }^{8}$

Berbagai permasalahan akan timbul dalam perkawinan yang dilakukan secara siri, hal tersebut tentunya tidak dapat dipungkiri karena suatu pernikahan siri tidak memiliki kekuatan di mata hukum negara. Maka dalam kehidupan suami istri tersebut akan dihadapkan pada masalah ekonomi karena pernikahan siri cenderung dilaksanakan atas ketidaksiapan calon pasangan. Selain itu juga berdampak terhadap masalah sosial yang mana akan timbul konflik atas pengucilan dan perspektif negatif dalam masyarakat kepada mereka yang melakukan pernikahan secara siri ${ }^{9}$ Secara hukum dalam

\footnotetext{
6 "Peraturan Pemerintah No. 9 Tahun 1975 Tentang Pelaksanaan Undang-Undang No. 1 Tahun 1974 Tentang Perkawinan," Pub. L. No. 1 (n.d.), https://peraturan.bpk.go.id/Home/Details/67678/pp-no-9tahun-1975.

7 Thriwaty Arsal, "Nikah Siri dalam Tinjauan Demografi," Jurnal Sosiologi Pedesaan 06, no. 02 (2012): 16069, https://doi.org/https://doi.org/10.22500/sodality.v6i2.6082.

8 Mahkamah Agung Rl, HIMPUNAN PERATURAN PERUNDANG-UNDANGAN YANG BERKAITAN DENGAN KOMPILASI HUKUM ISLAM SERTA PENGERTIAN DALAM PEMBAHASANNYA.

${ }^{9}$ Nurul Huda Haem, AWAS ILLEGAL WEDDING DARI PENGHULU LIAR HINGGA PERSELINGKUHAN, ed. oleh Muh. Iqbal Santosa, 1 ed. (Surabaya: Hikmah, 2007).
} 
pernikahan siri Istri tidak dianggap sebagai Istri sah, oleh sebab itu istri tidak berhak mendapatkan nafkah dan warisan dari suami jika meninggal dunia. Istri juga tidak berhak dalam menuntut harta gono-gini jika terjadi perceraian atas pernikahan yang dilakukan secara siri. ${ }^{\mathbf{1 0}}$

Kedudukan anak di dalam KUH Perdata terdapat 2 (dua) macam yaitu, anak yang dapat diakui dan anak yang tidak dapat diakui. Anak yang dapat diakui adalah anak yang lahir atas pernikahan yang dilakukan secara sah sesuai agamnya dan dicatat oleh pegawai pencatatan sipil sehingga kedudukan sang anak akan mendapatkan kekuatan di mata hukum dan berhak untuk mewarisi harta peninggalan kedua orang tuanya. Sementara anak yang tidak dapat diakui adalah anak yang lahir atas perkawinan yang tidak sah karena tidak dicatatkan oleh pegawai pencatatan sipil. Akibatnya anak yang tidak dapat diakui tidak berhak mendapatkan warisan atas kedua orang tuanya. ${ }^{11}$

Menurut Undang-Undang Nomor 1 Tahun 1974 Pasal 42 menyebutkan bahwa anak sah ialah anak yang lahir atas perkawinan yang sah. Kemudian dalam Pasal 43 menyebutkan kedudukan dari anak karena perkawinan siri hanya mempunyai hubungan perdata dengan ibunya dan keluarga ibunya. Dalam Pasal 44 suami berhak untuk membuktikan sah atau tidaknya anak jika dapat dibuktikan istri melakukan perbuatan zina. Lebih lanjut diatur pada Pasal 55 untuk membuktikan sah atau tidaknya seorang anak dapat dilakukan dengan melihat akta kelahiran otentik anak yang dikeluarkan pejabat yang berwenang. Apabila akta kelahiran tersebut dalam ayat 1 pasal ini tidak ada, maka pengadilan dapat mengeluarkan penetapan tentang asal-usul seorang anak setelah diadakan pemeriksaan yang teliti berdasarkan bukti-bukti yang memenuhi syarat. Atas dasar ketentuan pengadilan tersebut ayat 2 pasal ini, maka instansi pencatat kelahiran yang ada dalam daerah kerja hukum pengadilan yang bersangkutan mengeluarkan akta kelahiran bagi anak yang bersangkutan.

Akibat anak yang lahir atas pernikan siri maka tidak berhak untuk dapat memiliki akta kelahiran. Hal tersebut dikarenakan orang tua tidak dapat menunjukkan akta perkawinan. Padahal dalam Pasal 5 Undang-Undang Nomor 23 Tahun 2002 Tentang

\footnotetext{
${ }^{10}$ Abdullah Jayadi, Fenomena Nikah Siri: Perspektif Makna Pelaku Nikah Siri, ed. oleh M. Musfiqon, 1 ed. (Surabaya: Putra Media Nusantara, 2012).

${ }^{11}$ Addin Daniar Syamdan dan Djumadi Purwoatmodjo, "ASPEK HUKUM PERKAWINAN SIRI DAN AKIBAT HUKUMNYA," NOTARIUS 12, no. 1 (2019): 452-66, https://doi.org/10.14710/nts.v12i1.28897.
} 
Perlindungan Anak menyebutkan setiap anak berhak akan identitasnya dan status kewarganegaraannya. ${ }^{\mathbf{1 2}}$ Sebagai anak yang lahir diluar perkawinan yang sah, dapat membuat akta kelahiran melalui pencatatan kelahiran, tetapi nama orang tua yang tercantum hanya ibunya saja. Jika ingin mencantumkan nama ayahnya juga dalam akta kelahiran, diperlukan penetapan pengadilan sebagai bentuk pengakuan anak tersebut oleh ayahnya.

\section{Upaya Untuk Mencegah Pernikahan Siri}

Menurut sudut pandang pemerintah keberadaan pernikahan siri di Indonesia menimbulkan banyak polemik. Pernikahan Siri yaitu pernikahan yang dilakukan sembunyi, dan rahasia di Kantor Urusan Agama namun tanpa melakukan pencatatan sipil mengenai status perkawinannya. Dengan kata lain, nikah siri adalah pernikahan yang sah secara agama namun tidak sah secara hukum. ${ }^{\mathbf{1 3}}$

Dalam menyikapi keberadaan perkawinan siri ini, diperlukannya metode penyuluhan, edukasi dan evalusi untuk menindaklanjuti kasus tersebut. Guna pengedukasi ini untuk memberikan pemahaman akan pengetahuan serta menumbuhkan kesadaran terkait nikah siri dengan cara face to face bahkan langsung dengan orang yang ahli pada bidangnya. Banyak alasan yang meryertakan keberlangsungan perkawinanan siri yaitu dalam islam yang memperbolehkan menikah lebih dari 1 isteri hingga 4 dengan syarat adil. Selan tu keberadaannya sangat dipengaruhi oleh adat dan budaya setempat sehingga melahkan pemikiran pemikiran tersebut. Nikah siri juga dlkukan untuk menikahkan anak anak mereka dengan alasan untuk menjauh dari perzinaan.

Faktor faktor yang mendasari nikah siri yaitu faktor ekonomi, terletak diketidakmampuan dalam mebayar dan malas dalam mengurus pencatatan serta beralasan jauh dari tempatnya kemudian didukung dengan mata pencaharian mereka yang penghasilanya tak begitu besar hal ini terjadi. Faktor kedua yaitu adanya rasa malu karena telah mendaftarkan anak anaknya dalam pernikahan dengan sebab kecelakaan

12 "UU No. 23 Tahun 2002 Tentang Perlindungan Anak," Pub. L. No. 23 (n.d.), https://peraturan.bpk.go.id/Home/Details/44473/uu-no-23-tahun-2002.

${ }^{13}$ M. Yusuf M. Yusuf, "DAMPAK NIKAH SIRI TERHADAP PERILAKU KELUARGA," At-Taujih: Bimbingan dan Konseling Islam 2, no. 2 (2020): 96-108, https://doi.org/10.22373/taujih.v2i2.6530. 
dalam berinteraksi dan berhubungan. Faktor selanjutnya yaitu rendahnya kesadaran akan pentingnya hukum dalam pencatatan perkawinan. Sebagian orang menganggap pernikahan siri ini merupakan tradisi yang lazim oleh warga setempat dan telah membentuk pola pikir hingga membuat rendahnya sebuah kesadaran bahwa dengan adanya pencatatan pernikahan ini sangatlah pentng dalam pendokumentasian serta melindungi hak sebagaimana ia menjadi suami dan isteri yang bersangkutan dengan anaknya kelak. ${ }^{\mathbf{1 4}}$

Untuk menindaklajuti keberadaan nikah siri tersebut, peran KUA yaitu dengan penyuluhan pencatatan pernikahan dan keluarga bahagia di KUA kepada calon pengantin, sosialisasi tentang pentingnya pencatatan pernikahan dan dampaknya terhadap keluarga anaknya melalui seminar dan pengajaran, bekerjasama dalam menyelenggarakan penyuluhan serta pendekatan KUA sebagai kewenangnnya dalam mengurusi pernikahan. Melakukan penjadwalan penyuluhan Pencatatan Pernikahan dan Keluarga Bahagia yang dilakukan oleh Badan Penasehat, Pembinaan dan Pelestarian Perkawinan (BP4) di Kantor Urusan Agama kepada calon pengantin dan wali. Kantor Urusan Agama saling bekerjasama dengan rekan kerjanya yang berada di setiap desa yaitu P3N (Pembantu Pegawai Pencatat Nikah/ Amil Desa) bersama staff aparatur desa melakukan penyuluhan setiap 2 Bulan sekali kepada masyarakat yang diselenggarakan di Kantor Urusan Agama (KUA) Kecamatan dan juga sering diselenggarakan sesuai dengan kesepakatan yang telah disepakati untuk memberikan pemahaman dan penjelasan terkait pernikahan siri serta dampak-dampak yang timbul dan hak-hak yang tidak bisa didapatkan akibat melakukan pernikahan siri. ${ }^{\mathbf{1 5}}$

Selanjutnya peran dari pemerintah terkait pencegahan pernikahan siri agar dapat memberikan perlindungan kepada anak dari perkawinan siri. Upaya lainnya yang bisa dilakukan adalah menetapkan aturan terkait usia seseorang agar dapat melakukan pernikahan dengan adanya hal tersebut diharapkan dapat menekan angka pernikahan usia dini. Perlu adanya juga memberikan hak-hak berupa keuntungan bagi mereka

\footnotetext{
14 Jamaludin, "PERAN KUA DALAM MENGATASI NIKAH SIRI DI KECAMATAN METRO KIBANG KABUPATEN LAMPUNG TIMUR" (Institut Agama Islam Negeri (IAIN) Metro, 2019), https://repository.metrouniv.ac.id/id/eprint/772/1/JAMALUDIN 14117163.pdf.

15 Hanifah Romadhoni, Prihatina Prihatina, dan Solichah Novyana Putri, "OPTIMALISASI PERAN KUA DALAM MENGATASI ILEGAL WEDDING," Privat Law III, no. 2 (2015): 93-99, https://media.neliti.com/media/publications/164446-ID-optimalisasi-peran-kua-dalam-mengatasi-i.pdf.
} 
yang melakukan pernikahan secara sah baik secara agama maupun negara. Pemerintah pada awal pencegahan pernikahan siri dapat memberi nasehat melalui pegawai kantor urusan agama agar dapat mempertimbangkan tindakannya tersebut dengan menjelaskan akibat dari pernikahan siri, negatif pernikahan siri, serta segala hal yang akan di dapatkan jika melakukan pernikahan siri. Setelah memberi nasehat dilanjutkan memberikan sosialisasi kepada orang tua calon pasangan tersebut terkait kerugian yang akan timbul jika melakukan pernikahan secara siri. Memudahkan dan meringankan dalam upaya pelaksanaan pencatatan pernikahan. Meningkatkan moral serta mengubah pola pikir yang terjadi di masyarakat dalam memandang pernikahan siri sebagai sesuatu yang lazim dilakukan melalui iklan, anjuran, poster, spanduk dan lain sebagainya. ${ }^{16}$

Peran keluarga sangat penting dalam mencegah terjadinya pernikahan siri karena seperti disebutkan diatas salah satu faktor yang melandasi suatu perkawinan siri adalah karena keluarga kurang mendidik atau memperhatikan anak-anaknya dalam bergaul sehingga menyebabkan seorang anak terjerumus ke dalam pergaulan bebas. Demi menutup aib keluarga serapat-rapatnya dan mempertanggungjawabkan perbuatan si anak maka kedua keluarga sepakat untuk menikahkannya secara siri. Peran orang tua sangat penting sebab merupakan orang tua sebagai tertinggi dari lembaga keluarga. Memiliki hubungan erat antar anggota keluarga yang dilandasi dengan suasana penuh kasih sayang dan rasa tanggung jawab. Keluarga memiliki karakteristik yaitu hubungan yang intim, erat dan langgeng, memiliki tingkat kooperatif tinggi serta seringnya bertatap muka. Keluarga terutama orangtua memiliki kewajiban dalam pembinaan anaknya terkait moral. Keluarga sebagai lembaga terkecil dalam menjalankan tugasnya dalam lembaga sosial melakukan pembinaan pengarahan perlindungan yang berharap agar anaknya bisa tumbuh dengan bak dan memiliki moral yang baik juga.

Lain halnya jika perkawinan siri ternyata dilakukan seseorang yang dapat dikatakan sudah dewasa. Perkawinan siri tersebut cenderung dilakukan untuk melancarkan praktik poligami atau tidak adanya restu dari masing-masing pihak keluarga calon pasangan. Keluarga dapat hadir memberikan nasihat dan melakukan tindakan persuasif

\footnotetext{
${ }^{16}$ Wahyu Eko Susanto, "PERAN PEMERINTAH DESA DALAM PENCEGAHAN PERNIKAHAN DI BAWAH UMUR (Studi Kasus di Desa Gladagsari, Kecamatan Ampel, Kabupaten Boyolali)" (Institut Agama Islam Negeri (IAIN) Salatiga, 2018), http://e-repository.perpus.iainsalatiga.ac.id/5035/1/skripsi.pdf.
} 
untuk tidak melakukan poligami berdasarkan berbagai pertimbangan dan menilai nilai kemudharatannya. Peran orang tua juga dalam menentukan kemauan anaknya dalam memilih pasangan harus diberikan sebebas-bebasnya, orang tua hanya perlu memberikan pesan bahwa pernikahan harus dengan didasarkan pada pemantapan niat kedua calon dan kesiapan segala aspek demi menunjangnya suatu perkawinan. Perkawinan juga harus dimaknai sebagai perintah agama agar dapat membentuk keluarga yang sejahtera, bahagia, dan memiliki keturunan-keturunan yang terbaik. Maka dari itu disarankan untuk memilih pasangan hidup dengan mempertimbangkan dari akhlaknya, keturunan atau nasabnya, fisiknya, dan hartanya. ${ }^{\mathbf{1 7}}$

\section{Simpulan}

Pernikahan mengacu pada kesepakatan antara seorang laki-laki dan wanita untuk berkomitmen membentuk suatu keluarga yang bahagia lahir dan batin serta harmonis. Dengan demikian diperlukan suatu upaya yang pasti untuk dapat melakukan itu. Pernikahan secara sah yang diakui oleh negara dan agama akan membuat penilaian dari arti sebuah pernikahan itu menjadi sesuatu yang berharga. Praktik pernikahan siri sudah mengakar dan melekat pada masyarakat islam di Indonesia. Dalam masyarakat masih terdapat pemahaman sebuah pernikahan cukup sah dan sesuai dengan ajaran agama saja tanpa perlunya pencatatan yang dilakukan pemerintah. Pemahaman ini sangat keliru sekali dan membawa petaka nantinya dalam menjalani rumah tangga. Kedudukan anak, kedudukan harta, dan hak-hak tidak bisa di dapatkan karena status hukum yang tidak diakui sebagai akibat perkawinan yang tidak dilakukan pencatatan oleh negara.

Dalam penelitian ini membuktikan dampak yang akan datang sebagai konsekuensi pernikahan siri sangat banyak dan itu mempersulit kedua pasangan dalam mengarungi kehidupan rumah tangganya terlebih lagi apabila kedua pasangan tersebut bercerai tidak akan mendapatkan dari pada hak-hak keduanya. Penelitian ini juga memperjelas batasan dari pernikahan siri serta bagaimana hukum negara dan hukum islam memandangnya. Ditemukan juga salah satu faktor yang memperkuat terus

\footnotetext{
17 Kastolani, "Kumpulan Hadits tentang Jodoh, Ini Anjuran Menikah Dalam Islam," i. News.id, 2021, https://www.inews.id/lifestyle/muslim/hadits-tentang-jodoh.
} 
meningkatnya pernikahan siri disebabkan oleh marak terjadinya pernikahan usia dini sebagai akibat dari pergaulan bebas. Tidak dapat dipungkiri perkembangan zaman dan tekonologi membuat pergeseran nilai-nilai keagamaan dan sopan santun sehingga kita bangsa Indonesia yang menjunjung budaya timur ikut terbawa ke dalam arus perubahan tanpa kita sadari. Ini mengindikasikan perlu adanya pemantapan kembali nilai-nilai luhur dari bangsa Indonesia sendiri dengan berbagai kegiatan yang menambah kecintaan kita terhadap bangsa Indonesia. Dengan segala upaya yang dilakukan bukan tidak mungkin pernikahan siri dapat berkurang dan menghilang dari budaya masyarakat yang telah melekat sejak lama.

\section{DAFTAR PUSTAKA}

Arsal, Thriwaty. "Nikah Siri dalam Tinjauan Demografi." Jurnal Sosiologi Pedesaan 06, no. 02 (2012): 160-69. https://doi.org/https://doi.org/10.22500/sodality.v6i2.6082.

Haem, Nurul Huda. AWAS ILLEGAL WEDDING DARI PENGHULU LIAR HINGGA PERSELINGKUHAN. Diedit oleh Muh. Iqbal Santosa. 1 ed. (Surabaya: Hikmah, 2007).

Jamaludin. "PERAN KUA DALAM MENGATASI NIKAH SIRI DI KECAMATAN METRO KIBANG KABUPATEN LAMPUNG TIMUR". (Institut Agama Islam Negeri (IAIN) Metro, 2019). https://repository.metrouniv.ac.id/id/eprint/772/1/JAMALUDIN 14117163.pdf.

Jayadi, Abdullah. Fenomena Nikah Siri: Perspektif Makna Pelaku Nikah Siri. Diedit oleh M. Musfiqon. 1 ed. (Surabaya: Putra Media Nusantara, 2012).

Kastolani. "Kumpulan Hadits tentang Jodoh, Ini Anjuran Menikah Dalam Islam." i. News.id, 2021. https://www.inews.id/lifestyle/muslim/hadits-tentang-jodoh.

Kurniawati, Vivi. Nikah Siri. Diedit oleh Fatih. 1 ed. (Jakarta: Rumah Fiqih Publishing, 2019). https://www.rumahfiqih.com/pdf/x.php?id=171\&nikah-siri.htm.

M. Yusuf, M. Yusuf. "DAMPAK NIKAH SIRI TERHADAP PERILAKU KELUARGA." At-Taujih: Bimbingan dan Konseling Islam 2, no. 2 (2020): 96-108. https://doi.org/10.22373/taujih.v2i2.6530.

Mahkamah Agung RI. HIMPUNAN PERATURAN PERUNDANG-UNDANGAN YANG BERKAITAN DENGAN KOMPILASI HUKUM ISLAM SERTA PENGERTIAN DALAM PEMBAHASANNYA. Diedit oleh Mahkamah Agung RI. 1 ed. (Jakarta: PERPUSTAKAAN DAN LAYANAN INFORMASI BIRO HUKUM DAN HUMAS BADAN 
URUSAN ADMINISTRASI MAHKAMAH AGUNG REPUBLIK INDONESIA, 2011). https://perpustakaan.mahkamahagung.go.id/assets/resource/ebook/23.pdf.

Peraturan Pemerintah No. 9 Tahun 1975 Tentang Pelaksanaan Undang-Undang No. 1 Tahun 1974 Tentang Perkawinan, Pub. L. No. 1 (n.d.). https://peraturan.bpk.go.id/Home/Details/67678/pp-no-9-tahun-1975.

Romadhoni, Hanifah, Prihatina Prihatina, dan Solichah Novyana Putri. "OPTIMALISASI PERAN KUA DALAM MENGATASI ILEGAL WEDDING." Privat Law III, no. 2 (2015): 93-99. https://media.neliti.com/media/publications/164446-ID-optimalisasiperan-kua-dalam-mengatasi-i.pdf.

Susanto, Wahyu Eko. "PERAN PEMERINTAH DESA DALAM PENCEGAHAN PERNIKAHAN DI BAWAH UMUR (Studi Kasus di Desa Gladagsari, Kecamatan Ampel, Kabupaten Boyolali)". (Institut Agama Islam Negeri (IAIN) Salatiga, 2018). http://e-repository.perpus.iainsalatiga.ac.id/5035/1/skripsi.pdf.

Syamdan, Addin Daniar, dan Djumadi Purwoatmodjo. "ASPEK HUKUM PERKAWINAN SIRI DAN AKIBAT HUKUMNYA." NOTARIUS 12, no. 1 (2019): 452-66. https://doi.org/10.14710/nts.v12i1.28897.

UU No. 1 Tahun 1974 Tentang Perkawinan, Pub. L. No. 1 (n.d.). https://peraturan.bpk.go.id/Home/Details/47406/uu-no-1-tahun-1974.

UU No. 23 Tahun 2002 Tentang Perlindungan Anak, Pub. L. No. 23 (n.d.). https://peraturan.bpk.go.id/Home/Details/44473/uu-no-23-tahun-2002.

UU No. 23 Tahun 2006 Tentang Administrasi Kependudukan, Pub. L. No. 23 (n.d.). https://peraturan.bpk.go.id/Home/Details/40202.

UU RI No. 16 Tahun 2019 Tentang Perubahan Atas Undang-Undang No. 1 Tahun 1974 Tentang Perkawinan \& Kompilasi Hukum Islam. 1 ed. Bandung, Indonesia: Citra Umbara, n.d. 